\title{
الإعلام الإماراتى النشأة والتطور
}

(بتسام محمد ارحمه السويد(*)

إثر اف/ أ.د. سامى طايع(***)

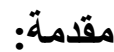

منذ قيام اتحاد دولـة الإمـار ات فى الثانى من ديسمبر عـام 1971 وهنـاك قفزة نو عيـة فـى كل المجـالات السياسية و الاقتصـادية و الاجتماعيـة فيى الدولـة سـواء على المستوى المحلى أو الاتحـادى، كمـا شـهدت العقود الثنلاثـة الأخيرة تطور اً هـائلاً فىى صناعة الإعـام فى دولـة الإمـار ات مـع صـدور عدة صـف بلغنات مختلفـة و إنشـاء محطات إذاعية وتليفزيونية فضائية متعددة، وبالمقارنة مع الدول المتقدمة فى الثرق الأوسط أو العالم العربى، يمكن اعتبار دولة الإمارات العربية المتحدة دولة تمتلك بنية تحتية هائلة لصناعة الإعلام مما كان له الأثر فى نوعية المـادة الإعلاميـة المنتجـة فى

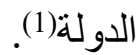

وتزخـر الدولـة بالعديـد مـن المؤسسـات الإعلاميـة المتكاملـة فـى العـدد والعـدة

خاصة مؤسسة دبسى للإعلام التى تشـرف على عدة قنوات تليفزيونيـة رائدة، وكذلك مؤسسة الإمار ات الإعلامية التى تدير جريدة الاتحاد وقناتى أبو ظبى و الإمـار ات، أمـا

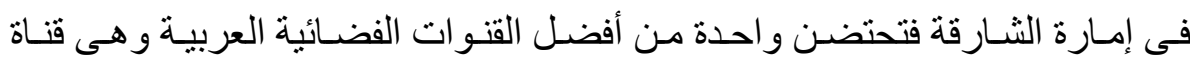
الثنارقة لما تتميز به هذه القناة من خطاب ثقافى ودينى رفيعين(2). و على الرغم من الإنجاز ات التـى تحققت فى الإمـار ات تتسم وسـائل الإعـلام باللامركزية فى الإدارة و الإشر اف مما ساعد على خلق تنوع فى الخطاب الإعلامى

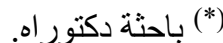
الأستاذ بقسم العلاقات العامة و الإعلان بكلية الإعلام - جامعة القاهرة. 
من جانب وتشابه فى مضامين الرسالة الإعلامية فى بعض الأحيان من جانب آخر ، ومن أهم التطور ات الإعلامية والسياسية ظهور مدينة دبى للإعلام كو احدة من أفضل المـدن الإعلاميـة فـى الثـرق الأوســـو إلغــاء وزارة الإعـلام الاتحاديـة واسـتبدالها بمجلس يشرف على الإعلام المحلى الإمار اتى.

وتتمتع دولة الإمار ات العربيـة المتحدة بكثافة إعلاميـة كبيرة جعلتها من أكثر الدول تشابكية Most Wired من حيث نسبة المنافذ الإعلامية لعدد السكان. وقد شـهد

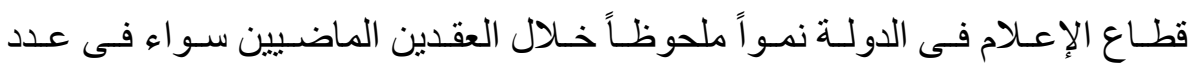
المؤسسـات و الأنشطـة الإعلاميـة أو مستوى التطور التكنولوجى. الإعلام فى دولة الإمارات .. خلفية تاريخية:

جاءت بدايات الإعلام فى الإمارات مع المرحلة الأخيرة من الوجود البريطانى فى المنطقة، والتى كانت قد حرصت فى بداية وجودها على سياسة العزل التام، ولكن بمرور الوقت وتغير الأوضـاع الاقتصـادية والاجتماعيـة اضطرت إلى تعديل بعض سياساتها بإنخال قدر من مظاهر التحديث إلى هذه الإمـار ات وذلك للتقليل من حدة الثعور المناهض للاستعمار البريطانى فى المنطقة والتى بدأ فى الظهور مـع بدايـة هجرة أبناء الإمار ات للدول المجاورة سواء للعمل أو طلب العلم، والتى كانت أكثر تطور اً ولعبت دور اً أساسياً فى انفتاحهم على العديد من الثقافات، هذا إلى جانب تأثير وصـول إرسـال الإذاعـات التـى بـدأت البـث للمنطقـة كإذاعـة صـوت العـرب و إذاعـة الكويت والقسم العربى لهيئة الإذاعة البريطانية ور اديو برلين(3). وبالنسبة للصحافة فقد انطلقت بعض التجارب الصحفية مع هذه الإمـارة أو تلك إلا نها لم تعدر طويلاً ولم تصبح الصحافة فى دولة الإمـار ات العربية المتحدة قوة مؤثرة إلا بعض صدور بعض الصحف اليومية منذ عام 1972. 
ويمكن القول أن أول من مارس الصـحافة غير الرسمية قبل قيام الاتحساد كان

السيد "إبر اهيم المدفع" من إمـارة الشـارقة عـام 1927، حيث أصدر صحيفة سميت "عمـان" تتكـون مسن صـحيفتين وتكتب باليد، ويوزع منهـا حو الى خمس نسـخ بـين الأصدقاء، و على بعض الثخصيات الذين يعرفون السيد إبر اهيم المدفع، الذى كان يجمـع المـادة من الصـحف التى تصـلهم متـأخرة فى ذللك الوقت مـن مصـر و العراق و الكويت، حيث يقوم بتدوين الأخبار الهامـة من هذه الصحف فى صحيفته ويكتب بعض الأشعار و الأدو ار الهامة فى إمارته بخط اليد، كذللك كتب "عمـان" موضو عات سياسية عن الأوضـاع الر اهنة وكفـاح عمر المختار والأحو ال فى فلسطين، وكانت تصدر مرتين شهرياً واستمرت لفترة تقارب السنة(4).

ومـن أوائل الذين مارسـوا الصـحافة مصبـح بـن عبيد الظـاهرى، الذى أسـس صحيفة "النخىى" عـام 1934، فـى مقهى صـغير كان يملكه فى مدينـة العين، وكان الظاهرى يكتب مو اد هذه الصحيفة بقلمه على أكياس الورق وسعف النخيل، وكانـا يقر أ المادة لمن لا يجيد القر اعة و الكتابة، واستمرت هذه المجلة لمدة ست عشرة سنة متو اصلة. وبدأت فكرة الصحيفة عندما دوّن الظـاهرى على كيس من الورق فو ائد حبوب "النخى" أى الحمص المسلوق و علقها على واجهة المقهى، وحظيت الورقة باهتمام الرواد فقام بنسخها وتوزيعها، لتبدأ بذلك أول صحيفة اقتصادية فى الإمـارات،

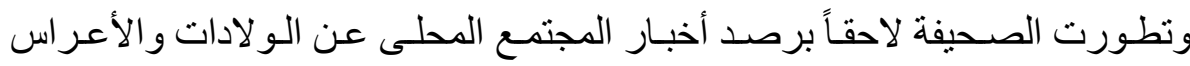

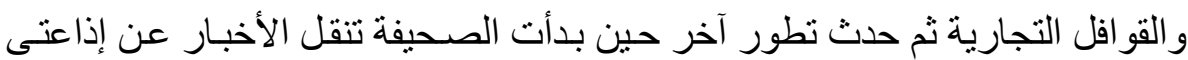

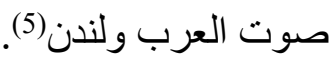
ومسع إثـر اقة حقبة الخمسينات حدث إزدهـار كبير لصـاحبة الجلالة بصدور مجلة الاتحـاد البريدى و العربى ونشـرة الديار ، ثم مجلة أخبار دبى فى عام 1965، و الجريدة الرسمية فى أبو ظبى فى عـام 1968، وشـهد عـام 1969 ظهور صحافة 
الاتحاد مع العدد الأول من جريدة الاتحاد، لتتبعها جريدة الخليج فى العام الذى يليه أى عام 1970، ثم نو الى ظهور الصحف والمجلات حتى فاق عددها العشرات. أمـا فـى مرحلـة الدولـة فيمكن اعتبـار العقد الأول مـن السبعينيات مـن أكثر

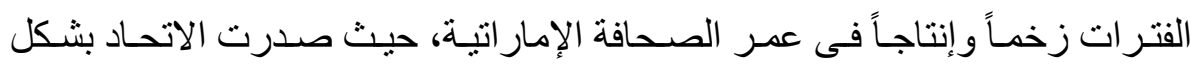
يومى فى 1972 والخليج فى 1970 و الوحدة 1973 وصسوت الأمـة 1975 وصحيفة الفجر 1977 والخليج تايمز 1978 و الإمار ات نيوز 1973 وهو العام الذى صد رفيـه أيضـاً قـانون المطبو عـات و الشـر و أخير اً صحيفة البيان التى جـاءت بداياتها متأخرة قليلاً حيث صدرت فى عام 1980 (6). و إذا مـا كانـت البـدايات شـهدت عو امسل عديدة عرقلت إصـدار الصـحف فـى الإمـار ات قبل مرحلة الدولـة (السبعينات) مثنل وجود الاستعمار البريطـانى وصـغر حجـم الســوق وقلــة الإعلانــات وتكــاليف النشـر، إضــافة إلـى تكــاليف التوزيــع و المو اصـلات، فـإن مرحلـة الدولـة و الإمكانيـات الاقتصـادية أنتجـت للصـحافة مجـالاً للتطور وحققت لها صفتى الاستمر ارية و المنافسة. وقد نشأت إذاعة صوت الساحل فى منطقة المرقاب فى الثـارقة، تأسست فى عام 1962 عن مكتب التطوير المنبثق من مجلس حكام الإمـار ات المتصـالحة الذى تأسسس عـام 1952، وكـان يهـدف إلـى العمـل فـى تحقيـق المصــالح المشـتركة بـين الإمارات، واستمرت الإذاعة عدة سنوات قبل الاتحاد، وفى العام 1970 توققت عن البث وحلت إذاعة دبى على التردد ذاتـ، كمـا تعد إذاعـة عجمـان من أوائل الإذاعـات فى الدولة، و التى بادر بها وأثرف عليها رائد عبد الله بن حمضة، من غرفة فى منزله فى مطلع الستينات، وقد انبهر الإنجليز عند سماعهم بـث الإذاعة فقدموا إلى حـاكم عجمـان الثـيخ راثـــــن حميد النعيمس، رحمـه الله طـالبين منـهـ زيـارة مقر الإذاعـة

$$
\text { و التعرف إلى مؤسسها. }
$$


أمـا إذاعـة عجمـان الجديـدة (الر ابعـة) فقد تأسسـت فـى سـبتمبر عـام 2001، بإثـر اف استـديوهات عجمـان الخاصـة، بهدف التواصـل بين أفر اد المجتمع وممثلى الدوائر الحكومية، وتتبعها عدة إذاعات تبـث بالإنجليزيـة والهندية و المليالم. وانطلقت إذاعة أبو ظبى فى فبراير 1969، وتغير اسمها فى عام 1971 إلى صوت الإمـار ات

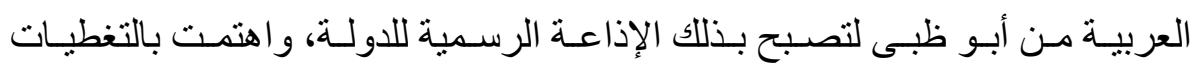
الخارجة للاحتفالات القومية. كما تأسست إذاعة القرآن الكريم فى عام 1979، و التى تختص بيث البر امج الدينية والفقهية الأسرية المتنوعة(7). أما إذاعة "إمار ات إف إم" فقد تأسست عام 1995، وهى من أكثر الإذاعـات جذباً للمستمع محلياً وخليجياً، بسبب طابعها الإمار اتى الخليجى الذى يغلب على جميع

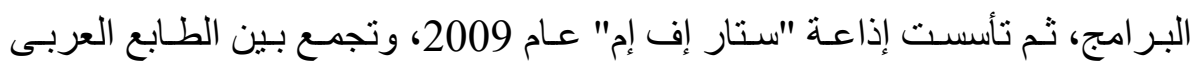
و الغربس إلى جانب بـث أحدث الأخبار العالميـة، وتستهدف فئسة الثباب العربى، ثم تأسست إذاعة أبو ظبى كلاسيك إف إم عام 2009، لتصبح أول محطة إذاعية تعنى بالموسيقى الكلاسيكية فى الدولة. وقد تأسست إذاعـة دبـى عـام 1971 على يد ريـاض الثـعيبى الذى انتقل من إذاعـة صوت السـاحل بعد إغلاقها إلى إذاعـة دبى، وحلت محل تردد إذاعة صسوت السـاحل، حيـث كانت معنيـة بـالبر امج الإخباريـة، وبر امج البـث المباشـر التى تهدف للتو اصل مع الجمهور و الاستماع لمشاكلهم و السعى لحلها، إلى جانب البر امج التقافيـة و الثعرية الهادفة(8).

ويعتبر تليفزيون الإمـار ات من أبو ظبى أول جهاز بـث تليفزيونى فى دولـة

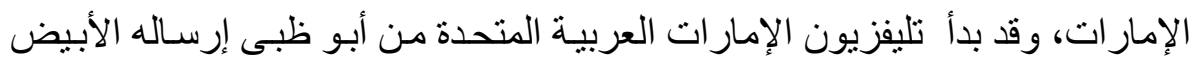
و الأسود يوم 1969/8/6 بينما بدأ إرسـاله الملون فى 1974/12/4، وتليفزيون دولة الإمارات العربية المتحدة عضو مؤسس فى جهاز تليفزيون الخليج وفى اتحاد إذاعـات الدول العربية واتحاد إذاعات الدول الإسلامية واتحاد إذاعات الدول الآسيوية وعضو 
منتسب فى اتحساد إذاعـات الدول الأوروبيـة. وقد بـد الإرسـال التلبفزيونى على القتاة الفضـائية لتليفزيـون الإمـار ات العربيـة المتحدة مـن أبو ظبـى بتـاريخ 1992/11/15 ويستخدم القمر الصناعى العربى عربسات فى البث.

وقد تز امن مع بناء ميناء راشد فى دبى افتتاح إذاعة دبى ومطار دبى الحديث وافتتاح المحطة الأرضية للأقمار الصناعية وميناء جبل على وكذلك افتتاح التلبفزيون الذى كان منذ نشأته و انطلاقته فى الثانى من ديسمبر عام 1974 مركز اشعاع إعلامى وثقافى وحضارى للمنطقة(9).

فقى الثانى من ديسمبر 1974 افتتح الثيخ راشد بن سعيد آل مكتوم تليفزيون دبى وكان من أوائل التليفزيونات الملونة فى الخليج و المنطقة العربية. وقد بدأت تلك ديك المحطـة بثهـا المنتظم عـام 1976 وكانت تسـى لجذب أكبر جمهور ممكن لزيـادة إعلاناتها وكان ظهور هذه المحطة أمراً طبيعياً بسبب إزدهـار النشـاط التجارى فى هـ دبى ورغبة الإمارة فى التنافس مع المحطات الخليجية الأخرى التى سبقتها فى إدخال التليفزيـون الملـون. وفى عـام 1978 ثم افتتـاح البـث التليفزيـونى باللغــة الإنجليزيـة لتغطية جانب هام من وسائل الاتصال مـع جمهور المشـاهدين غير الناطقين بالعربيـة وقد أحدث تليفزيون دبى تطور اً إعلامياً ملموسـاً فى الفترة الماضية بدخولـه مجـال الإنتاج و التسويق التليفزيونى، وبهذا لم تعد الإمار ات سوقاً استهلاكية لمثل هذا الإنتاج بل تحولت إلى منتج منميز لإنتاج العديد من البر امج و المسلسـلات التليفزيونية الهادفة التى تعرضها معظم تليفزيونات الدول العربية. وقد نم افتتاح تليفزيون الثـارقة فى الحادى عشر من شـهر فبر اير عام 1989، و هو جهاز إعلامى ملتزم ومسؤول، تأسس ليكون منـارة من منـار ات الثقافة و الفكر و الأدب و القيم الأصيلة فى مجتمع الإمـار ات و المنطقة، افتتحهـ صـاحب السمو الثيخ الدكتور سـلطان بـن محمد القاسـى عضـو المجلس الأعلى للاتحـاد حـاكم الثـارقة، ليكون ضيفاً على كل بيت إمار اتى، و لا يز ال يو اصل عطاءه الثرى منذ 21 عاماً على بلى 
نفس المناهج الذى تأسس فى ضوئه. وفى تليفزيون عجمان بدأ البث الأرضى فيه عـام 1996، وفى عام 1998 بدأ البث الفضائى(10).

وصلاحيات الوزر اء. وتتمثل صلاحيات المجلس (كما وردت بالمرسوم ونظسام

الإنثاء) بما يأتى: الاضطلاع بكافة شؤون الإعلام وصلاحياته المنصوص عليها فى القانون رقم 15 لسنة 1980 بشـأن المطبو عـات و النشـر ـ والاضطلاع بكافـة الشؤون المنصـوص عليهـا فـى القرار ات الصـادرة مـن مجلس الـوزر اء ذات الصـلة بعهـل المجلس. و أيـة اختصاصـات أخرى تخول إليسه بمقتضى القو انين و اللو ائح وقر ار ات مجلس الوزراء. وصدر نظام المجلس بموجب قرار مجلس الوزراء رقم 14 لسنة 2006م وقـرار مجلس الـوزر اء رقـم (8) لســة 2007م. ويسـعى المجلس لتحقيـق

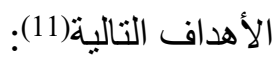

* توفير بيئة تنظيمية متكاملة تسهم فى تطوير قطاع الإعلام فى دولة الإمار ات. * إبراز إنجاز ات دولة الإمار ات إعلامياً فى الداخل والخارج. * ضمان أن جميع الخدمات الإدارية و اللامركزية تتم بجودة عالية وكفاءة وشفافية

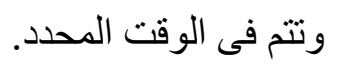

وكان فى مقدمة القوانين التى تنظم عمل وسـائل الإعلام فى دولة الإمـار ات القانون الاتحادى رقم (15) لسنة 1980 فى شـأن المطبو عـات و النشـر و الذى اشترط لمالك المطبعة و المسئول عن إدارتها ما يلى (12):

$$
\text { 2- } 1 \text { - أن يكون من مو اطنى الدولة. }
$$

3- أن يكون محمود السيرة حسن السمعة. 
4- ألا يكون قد سبق الحكم عليه فى جريمة مخلة بالثرف أو بالأمانة ما لم يكن قد رد إليه اعتباره أو صدر عفو عنه من السلطات المختصة. كما نصت المادة (24)(13) على أنه لا يجوز إصدار صحيفة إلا بعد الحصول على ترخيص بذلك وفق أحكام هذا القانون: أمـا المـادة (25) من القانون(14) فاثترط

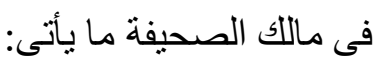

1- أن يكون من مو اطنى الدولة المقيمين فيها على وجـه الاعتيـاد و لا يسرى هذا الثـرط بالنسبة إلى المطبو عـات الدوريـة التـى تصـدر ها البعثـات الدبلوماسـية و القنصلية ونشر ات وكالات الأنباء الأجنبية المرخص لها بالعمل فى الدولة. 2- ألا يقل سنه عن خمس و عثرين سنة ميلادية. 3- أن يكون كامل الأهلية. 4- أن يكون محمود السيرة حسن السمعة. 5- ألا يكون قد سبق الحكم عليه فى جريمة مخلة بالثرف أو بالأمانة ما لم يكن قد رد إليه اعتباره أو صدر عفو عنه من السلطات المختصة.

$$
\text { 6ـ ألا يكون شاغلاً لوظيفة عامة فى الدولة. }
$$

وبشأن رئاسة تحرير الصحيفة تتص المـادة (26)(15) على عدم جواز عرض أى فيلم سينمائى أو إثارة إلى فيلم أو إعلان تجارى بصورة سينمائية فى إحدى دور العرض بالبلاد قبل الحصول على ترخيص بذللك من لجنـة مر اقبـة الأفلام السينمائية ويصدر بتحديد الوثائق التى يجب أن نرفق بطلب الحصول على هذا الترخيص قرار من الوزير. 
المؤسسات الإعلامية الاتحادية فى دولة الإمارات:

مـع تــامى النهضـة الحضـارية فى دولـة الإمـار ات وتز ايد احتياجـات المجتمع

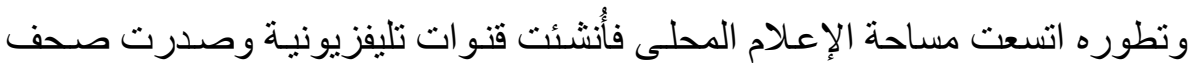
حكو ميـة وخاصـة ممـا اسـتـعى وضـع تشـريعات وقـو انين لضـبط المسـار وصـيانة الحقوق الفردية والعامـة وتحديد المسؤوليات والإلتز امـات. ودخل الإعلام فى الدولـة مرحلـة تطور بإقامـة المؤسسـات العامـة و الثـاملة لمختلف جوانب العمل الإعلامسى المرئى و المسموع مثل مؤسسة الإمار ات للإعلام ومؤسسة دبى للإعلام. أما ذروة هذا التطور فتمثلت فى إنشاء المدن المتخصصة فى مجالات الإعلام وميـادين الاتصـالات و المعلومـات المتتوعـة مثنل مدينـة دبـى للتكنولوجيـا و الإعـلام ومدينة دبى للإنترنت فضلاً عن المدن المتخصصـة فى مجالات أخرى وغير هـا من المشرو عات الكبرى التى تشهدها الدولة عامة و إمارة دبى بصفة خاصة.؟ وفيمـا يلـى عرض لأبـرز المؤسسـات الإعلاميـة فـى دولـة الإمسارات سـواء

الصحفية أو الإذاعية أو التليفزيونية:

$$
\text { مؤسسة أبو ظبى للإعلام: }
$$

أبو ظبى للإعلام هى إحدى أسرع المؤسسات الإعلامية نمواً فى منطقة الثرق الأوسـ، ولديها شـريحة واسـعة مـن المنتجـات الإعلاميـة فـى قطاعـات التليفزيـون، و الر اديو، و النشـر ، والإعلام الرقمى. وتقوم الثـركة بإدارة مـا يزيد عن 20 علامـة تجارية فى مجالين: علامات تجارية تتوجـه إلى الإمـار ات العربيـة المتحدة من خـلال دور محدد بالخدمة العامة، و علامـات تجاريـة تتوجـه إلى العـالم العربى وذات أهداف

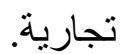

وتعتبر أبو ظبى للإعلام الثـركة الوحيدة فيى الإمـار ات التى تمتلك علامـات

تجاريـة تشـل جميع قطاعـات الإعلام، وتتحلى بدور أساسـى تجـاه المتمـع المحلى 
لناحيـة تقديم بـر امج تعنـى بالترفيـه و الأخبـار و الثقافـة. ويقوم بهـذا الـدور عدد مـن العلامات التجاريـة مثل صحيفتى الاتحـاد وذا ناشيونال، وقنوات أبو ظبى الإمـار ات وأبو ظبى الرياضية، و إذاعات القرآن الكريم و إمارات أف أم و أبو ظبى أف أم وستار أف أم ومجلة الأطفال ماجد. (16)

كما تتمتع أبو ظبى للإعلام بأهداف تجارية، تستهدف المر أة و العائلة من خـلال علامات تجارية تصل إلى جميع أنحاء العالم العربى، وتتضمن قناة أبو ظبى الأولى،

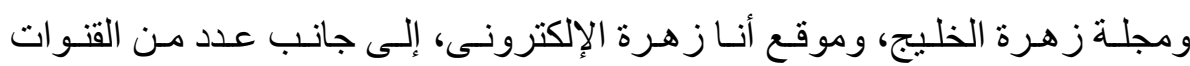
التليفزيونية المدفو عة ولوسائل الرقمية.

وتمتللك أبو ظبى للإعلام وتشغل شركات تابعة تعمل فى مجالات عدة ومنها ايمح نيشن أبو ظبى و التى تختص بإنتاج الأفلام المحلية؛ و لايف، العاملـة في مجـال الإنتاج و البث الخارجى؛ و الثركة المتحدة للطباعة و النشر ، إلى ذلك، تقيم أبو ظبى لبـ

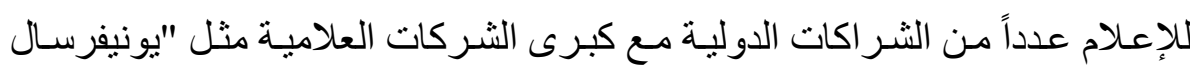
ميوزيـك جـروب" و"سـونى ميـوزك إنترتينمنـت ضـــن "يفيفو " VEVO، البوابـة الإلكترونيـة المخصصــة للموسـيقى المصــورة علـى شـبكة الإنترنــات، وناثــيونال جيو غر افيك فى إطار قناة ناشيونال جيو غر افيك أبو ظبى ومجلة ناشيونال جيو غر افيك العربية.

و تشنمل مؤسسة أبو ظبى للإعلام صحيفتى "الاتحاد" و "ذا ناثنيونال" ومجـلات

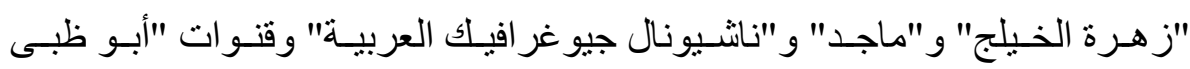
الأولى" و "أبو ظبى الرياضية" و أبو ظبى الإمارات" و "أبو ظبى در امـا" و "ناشتيونال جيو غر افيك" و إذاعات "القرآن الكريم" و إمار ات أف أم" و "أبو ظبى أف أم" و"ستار

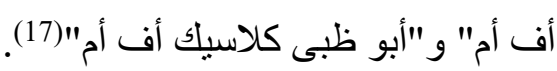


ومسن أهـم مـا يصـدر عن المؤسسـة جريـدة الاتحساد التىى صـدرت عن دائرة

الإعـلام و السياحة فى إمـارة أبـو ظبى 1969 ثم تحولت إلى الإصـدار اليومى فـى 1972 وقد لبعت الصحيفة دور اً سياسياً وإعلامياً هامـاً أيسام مداو لات قيام اتحاد دولة الإمار ات، حيث تبنت خطاباً يهدف لخدمة الاتحاد و إنجاحه وتحقيقه على أرض الواقع وفى 21 مسارس 1977 أصدر رئيس دولـة الإمـار ات مرسواً اتحادياً بإنشـاء مؤسسـة الاتحاد للصحافة والنشر و التى يصدر عنها حالباً إلى جانب الصحيفة اليوميـة، مجلة نسـائية أسبو عية (زهرة الخليج) ومجلة للأطفال (ماجد) وصحيفة باللغـة الإنجليزيـة

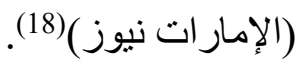

وتعتبر الاتحاد الناطق الرسمى باسم حكومـة الاتحساد إذ تقوم الصحيفة بإبراز أخبار الحكومة الإمار اتية على صفحتها الأولى خاصـة مـا يتعلق بالإنجـاز ات التتمويـة التى تحققت فى دولة الإمار ات العربية المتحدة(19). أمسا مجلةز هرة الخليج فقد صدرت العدد الأول منها فى 21 مسارس 1979 وتعتبر أحد المجلات النسائية العربية الهامة ومن أكثرهـا رواجاً، وتعتبر مجلة ماجد التى صدر العدد الأول منها فى 28 فبر اير سنة 1979 من أفضل مجلات الأطفال فى الوطن العربى و أكثر ها توزيعاً. ويصدر عن المؤسسة أيضاً مجلة الكمبيونر و التكنولوجيا الثهرية وكذلك ملف شهرى بأهم ما ينشر فى الصحف و المجلات العربيـة والأجنبيـة من القضـايا التى تهم

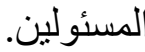

وتعتبر جريدة الاتحساد واحدة مـن أهـم وأثــهر الصـحف الصـادرة فـى دولـة الإمـار ات، فقد صـدر عددها الأول فـى 20 أكتوبر 1969 فـى الفترة التـى شـهـت المباحثات التى كان يجبر ها الثيخ زايد بن سلطان آل نهيان، حاكم أبو ظبى آنذاك، مـع 
إخو انه حكام الإمار ات الأخرى لقيام اتحاد دولـة الإمـار ات العربيـة المتحدة، ومن هنـا جاءت تسمية الجريدة "الاتحاد" لتكون لسان حال الدولة ككيان وحدوى. وقد صـدر العدد الأول مـن جريدة الاتحساد فى 20 أكتوبر 1969 فى فترة

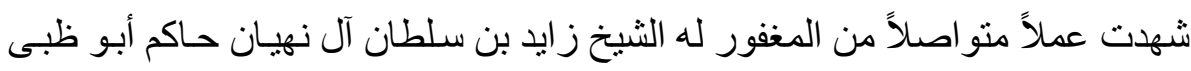
حينئذ إذ كـان يقوم حينها بجهود مكتفة مـع إخو انـه حكام الإمـار ات لقيام اتحساد دولـة

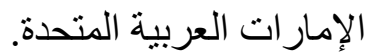

ولعل تسمية "الاتحـاد" تحمل مـن الرمزيـة والمعـانى الكبيرة مـا يعكس كون جريـدة "الاتحـاد" لسـان حـال دولـة الإمـار ات، ليس فقط كمجتمع بـل ككيـان سياسى مشهود له بالمو اقف و التوجهات الموضوعية. ويذكر أن الجريدة بدأت بالصدور بشكل أسبو عى من 12 صفحة ووصل حجم توزيعها إلى 5500 نسخة، كما أنها كانت توزع مجاناً للصمود فى وجه الصحف المنافسة القادمة من بعض الأقطار العربية الأخرى. ومع إعلان قيام دولـة الإمـار ات فى العـام 1971 صدرت "الاتحساد" لعدة أيسام متتالية كما صدرت بشكل يومى لمدة أسبو عين فى 6 أغسطس 1971 وذلك لمناسبة الذكرى الخامسة لتولى صاحب السمو الثيخ زايد بن سلطان آل نهيان مقاليد الحكم فى أبو ظبى(20).

و اعتبارًا من 22 أبريل 1972 بدأت جريدة الاتحاد بالصدور يومياً وهى اليوم تصدر بحلة منطورة تتضـن 32 صفحة منها عدة صفحات بـالألو ان. وفى مرحلة

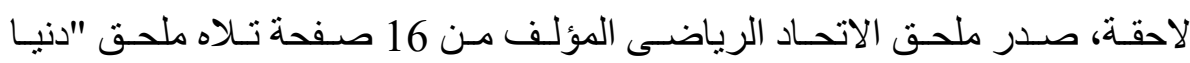
الاتحاد" وهو عبارة عن مجلة يومية فنية ثقافية منو عة من 16 صفحة أيضـاً. ويسجل لجريدة الاتحاد استعمالها لتقنية نقل المواد الصحافية بواسطة الأقمـار الصناعية للمرة الأولى فى البلدان العربيـة فى عام 1981 عندما أنشـأت مطبعة ثانيـة فى دبى لتطبع الجريدة فى كل من أبو ظبى ودبسى فى الوقت نفسـه وذللك للتخلب على مشـاكل تأخر 
التوزيع فى الإمـار ات الثمالية. و اليوم تمتلك الاتحساد واحدة من أحدث المطابع فىى الثرق الأوسط وينعكس ذلك على نوعيـة الطباعة التى تضـاهى بجودتها الصـحف وله

يعمل فى الاتحاد اليوم ما يقارب المئة صحافى ينوز عون بين أبو ظبى ومكاتب

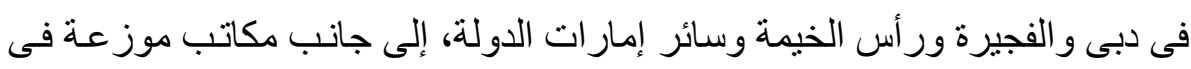
بيروت و القاهرة ومر اسلون فى أنحاء العالم ويعتمد الصحافيون فى عملهم على أحدث

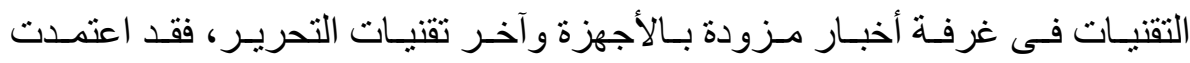
"الاتحـاد" مؤخر اً برنـامج "ر ابيد بـر اوزر" الخـاص باستقبال أخبـار وكالات الأنبـاء وتحرير ها ومتابعتها حتى وصسولها إلى مرحلة الطباعـة. الجدير ذكره أن "الاتحاد" دخلت عالم الإنترنت اعتبار اً من يوم الجمعة فى 15 مـارس 1996 لتقدم إلى قر ائها خدمة جديدة لتكون بذلك أول صحيفة محلية تقدم هذه الخدمة.

ومن أبرز القنوات التى تضمها مؤسسة أبو ظبى للإعلام قناة أبو ظبى الأولى وتعتبر قناة أبو ظبى الأولى الامتداد الأول لتلفزيون الإمار ات العربية المتحدة من أبو ظبى إلى جانب القنوات الأخرى. حيث بدأ التليفزيون إرسـاله فى أغسطس 1969م

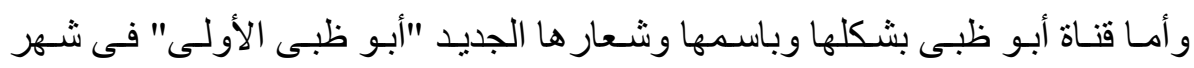
أكتوبر عام 2008.

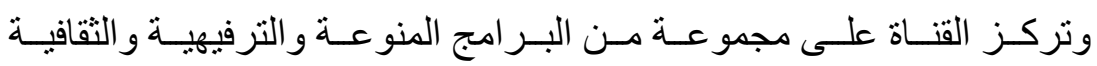
و الاجتماعية والحوارية و التقارير و المسلسلات الدر امية والأفلام العربية الموجهة إلى جميع أفر اد العائلـة العربيـة. إضـافة إلى نشـرة الأخبار المميزة التى ينم إرسـالها إلى جميع منطقة الثرق الأوسط وشمال إفريقيا(21). 
استطاعت مؤسسـة دبـى للإعـلام و عبر قنو اتها الإعلاميـة المتعددة (الصـحافة

الورقيـة و الإعـلام المرئسى و المسـموع) أن تحقـق الكثيـر مـن النجاحـات على صـعيد الإعلام فى العالم العربى، وبعد أن وصلت إلى شريحة واسعة من الجمهور العربى و العالمى من خلال بر امجها ومو ادها الإعلامية المتنو عة و المتجددة و التى تعكس على الدوام روح الأصالة والتجديد بعيداً عن نمطية البرامج الكلاسيكية(22). فمـن خـلال رؤيتهـا الإعلاميـة الو اضـحة الملامسح، المرتكـزة علـى الابتكــار و الجودة ومو اكبة الغايات الإستر اتيجية لحكومة تسعى مؤسسـة دبى للإعلام للوصول إلى إعـلام عربـى متميز يو اكب روح العصـر ، ويقدم محتوى مبـدع و هـادف يحترم أسلوب الحياة الاجتماعية و الثقافية فى الإمار ات العربية المتحدة والدول العربيـة، إلى جانب ترسيخ تقاليد وثقافة العمل الإعلامى الاحتر افى الجـاد لدى العاملين فى الوسط الإعلامسى وصـو لاً إلى إيجـاد جيل متكامـل من الإعلاميين الإمـار اتيين القادر على

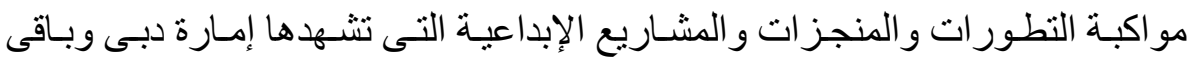
إمار ات الدولة، مما يساهم فى صياغة مفهوم جديد للإعلام التليفزيونى المعاصر. وتضم مؤسسة دبى للإعلام القنو ات التالية: "دبسى" و "سما دبى" و "دور دبى" و "دبى ريسنغ" و "دبى ون" و "دبى الرياضية"، و "إذاعة نور دبى" و إذاعـة "دبى إف إم"، وصـحف هـى: "البيـان" و"الإمـار ات اليـوم" و"24/7 Emirates" ومطـابع

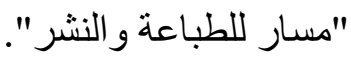

وقد صدرت جريدة البيان عن إمارة "دبسى" فى عام 1980 وهى بذلك تعتبر آخر الصحف الصـادرة فى الإمـار ات العربيـة المتحدة بتمويل من الحكومـة المحليـة، وتعكس الصحيفة طابع الإمارة الاقتصادى. وقد انعكس ذلك على مادتها التحريريـة، حيث تعتبر أول صحيفة فى المنطقة تخصص صفحتين يوميتين للثـئون الاقتصسادية 
المحليـة و الدوليـة ويصــر عـن مؤسسـة البيـان للصـحافة و النشـر مجلـة "الرياضــة و الثباب" كمجلة أسبو عية منو عة(23).

فقد كانت هناك حاجة فعلية لإصدار صحيفة يومية تعكس تقدم الحياة وتطور هـا فى دبى حيث كان القارئ منتوقاً ليرى هذه الصحيفة وخاصـة أنه كان هناك تركيز للصـحف و المطبو عـات فـى أبو ظبـى. ووقع الاختيـار على تسـية الجريدة الجديدة (البيان) لأن الكلمـة عربيـة ولفظ قرآنى وليس هنـاك من هدف سياسى ور اء التسمية وكان من الاسماء المقترحة الوصل و هو اسم دبى القديم ولكن الر أى استقر أخيراً على البيان و هى كلمة يقصد بها البلاغ وتعنى قول الحق وإبلاغ الحقيقة للناس(24). وجريدة البيان صحيفة يومية شاملة تأسست عام1980 بموجب مرسوم أصدره الثـيخ راشـد بـن سـعيد آل مكتوم، حيـث حلت "البيـان" مكـان جريـدة "أخبـار دبـى" الأسبو عية، وقد صـدر العدد الأول مـن "الييان" فـى العاثـر مـن مـايو العـام 1980 فأصسبحت الصـحيفة الخامسـة الصـادرة فى الدولـة وأول صـحيفة عربيـة تخصسص التص صفحتين ثم ثناثاً فأربعاً للمال و الأعمال، وهى الصـحيفة العربيـة الوحيدة التى منحت الثأن الاقتصادى الأولوية حيث قدمته فى التبويب على الثـأن المحلى. وصدر العدد الأول مـن "البيـان" في 20 صفحة، تم مـا لبتثت أن أطلقت سلسـلة ملاحـق أسبو عية متخصصـة فـى مجـالات متباينـة مستهدفة خدمـة القـارئ وجذبـه ليصبح عدد البيـان يلامس المائة صفحة يو مياً.

فـى العـام 1997 صدرت "البيـان" فـى حلَّة جديدة تركَّز الاهتمـام فيهـا على هـ تجويد المضـمون و الثـكل، وبرقت فـى هذه المرحلـة أسماء عدد مـن كُتّاب العمود المو اطنين أبرز هم عبد الحميد أحمد وعائشة سلطان ومرعى الحليان وفضيلة المعينى بإيقاع يومى، بالإضافة إلى كُتاب زو ايـا أسبو عية مثنل سـامى الريـامى، فاطمـة محمد

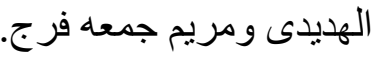


أصدرت الصـحيفة الطبعة الدوليـة وتشتمل على صفحات الجريدة الرئيسية وتصل إلى أقطاب العـالم وتوزع فى اليوم نفسـه. وفى يونيو 2003 دخلت "البيـان" عصر الصحافة الإلكترونية فأضافت بعداً جديداً إلى موقعها الإلكترونى وجمعت بين

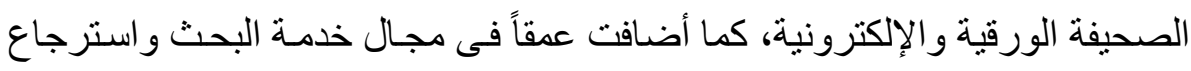
المعلومات، ذلك أن الموقع الإلكترونى أتاح بوابة إضافية لبنك المعلومات(25). وقد طورت البيـان إمكاناتها الطباعيـة خاصـة بعد افتتاحهـا لمطبعتهـا الجديد، و هـى ذات امكانـات أفضـل وسـر عة أكبر فى الطبع وجـودة فى الإنتاج ووضـح فـى درجات الألو ان مما أتاح طباعة 50 ألف نسخة فى الساعة لصحيفة عدد صفحاتها 48 صفحة مع الألوان(26).

أمـاصــيفة "الإمـار ات اليوم" فهى صـحيفة محليـة، بـالقطع العـالمى الجديـد، تصدر عن مؤسسة دبى للإعلام، وقد صدر العدد الأول منها فى 19 سبتمبر 2005، وتركز فى مجمل محتو اها على الثأن المحلى، و القضـايا التى تهم القر اء العرب فى لى دولة الإمار ات العربية المتحدة، ضمن سياسة تلتزم بالثروط المهنية للعمل الصحافى القائم على الدقـة و التـوازن و الموضـو عية، وتسـعى فـى الوقت نفسـه لتلبيـة منطلبـات القر اء فى المعرفة والترفيه الذكى، وتحـاول من خـلال صدور ها بـالقطع المصغر أن تتكيف مـع التغيير ات العالميـة فـى هذا المجـال، وتطـور أسـاليب القر اءة والتصفح، استجابة لمتطلبات الحياة العصرية، ويُنتج الصحيفة فريق محترف من الصحافيات و الصحافيين الثباب(27). ومن القنوات الثهيرة التى تتبع مؤسسة دبى للإعلام قناة دبى انطلقت قناة دبى متوجهة إلى المشـاهد العربـى فى مختلف أنحساء العـالم. وتمكنت من تحقيق حضور مميـز لـدى شـريحة كبيـرة مـن الجمـاهير العربيـة لتصـبح واحدة مـن أبـرز القــوات التلفزيونية الر ائدة التى تستهدف الأسرة العربية بأعمـال متوازنـة وذات مصداقية دون إغفال للتر ات المحلى و العربى، من خـلال بر امجها الإخباريـة والاجتماعيـة و الدر اميـة 
و الثقافية و الفنية الثرية. تسعى قناة دبى إلى ربط المشاهد الإمار اتى و المشاهد العربى بما يدور فى أرض الإمار ات و المنطقة والعالم، لتتيح متنفسـاً لأبناء الإمـار ات للتعبير

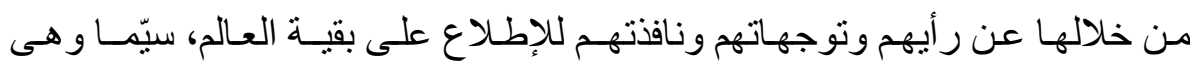
الناقل الرسمى للأحـداث و الفعاليـات المقامـة فى دبى وصـاحبة الحقوق فى الترويـجـ لها تلفزيونياً.

وفى ظل مؤسسة دبى للإعلام قدمت قناة دبى مجمو عـة من البر امج المتميزة

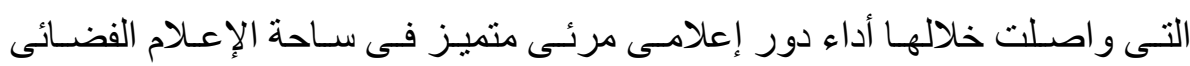
العربى. وحفلت القناة بالعديد من البر امج الإخباريـة و السياسية و الاقتصـادية إضـافة إلى التغطية المميزة لأحداث العـالم من خـلال مركز الأخبار الذى يعد نقطة مضيئة و إنجاز إ إعلامياً فى سماء الإعلام الإخبارى العربى. وتسعى قناة دبى لإنتاج البر امج

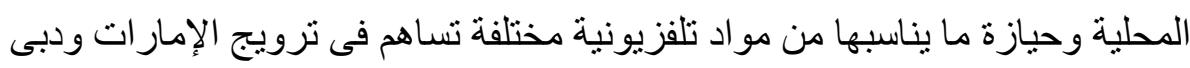
خصوصاً وتعكس نجاحها على كافة المستويات للعـالم، هى قناة ناطقة باللغـة العربيـة

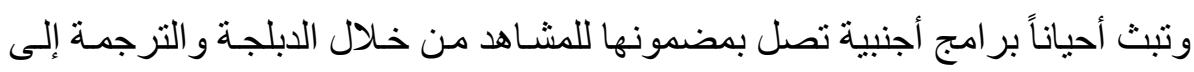
اللغة العربية(28). مؤسسة الشارقة للإعلام: و هـى مؤسســة حكو ميسة تعنسى بتتميسة وتطـوير القطـاع الإعلامسى فـى إمسارة الثـارقة، تأسست عـام 2009 بموجب المرسـوم الأميرى السـامى رقم 25، وتتمثل أهداف المؤسسة فى المساهمة بتطوير الكوادر الإعلامية الوطنية القادرة على مو اكبة

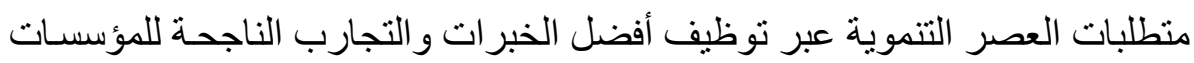
الإعلاميـة العامـة والخاصـة فـى الدولـة بالتنسـيق مـع الجهات المعنيـة، وتعزيـز دور الإعلام خاصة فى مجال بناء الأسرة وتر ابطها، وتطوير الأداء الإعلامسى ليقوم على

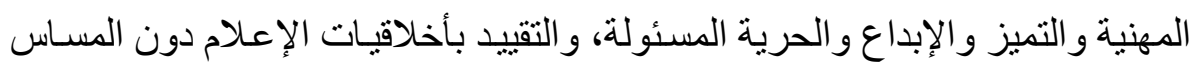


بحقوق الآخـرين، وتعـزيز القدرة التنافسية لوسـائل الإعـلام فـى الإمـارة مـع وسـائل

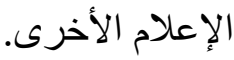

وتختص مؤسسة الثشارقة للإعلام برسم الخطة الإعلاميـة للإمـارة انسجاماً مـع

السياسة العامة للإعلام فى الدولة بالتنسيق مـع السلطات الاتحاديـة المتخصصـة لها

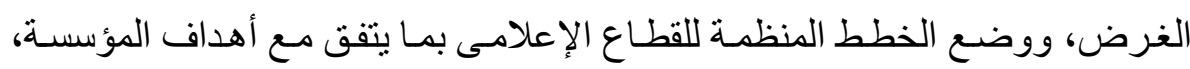
و إجـر اء الدر اســات و البحـوث و إعداد التقـارير المتعلقـة بأهـداف المؤسســة ونشـر ها، وتفعيل التشريعات الخاصـة بشؤون الإعلام في الإمـارة، ورفع الملاحظـات المتعلقة بتطوير ها لسمو الحاكم، وتبادل الخبر ات مـع المؤسسـات و الهيئـات المثيلـة فى الدولـة وخارجها، متابعة الأنشطة الإعلامية فى الإمـارة، و إنشـاء الوسـائل الإعلاميـة المرئية

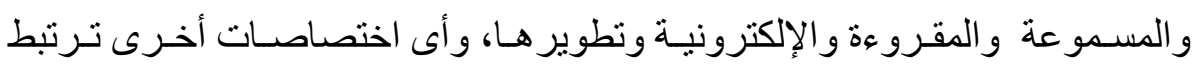

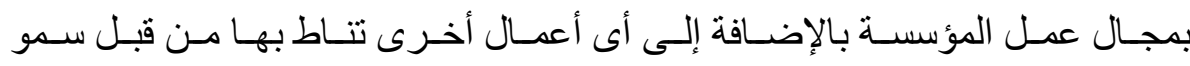

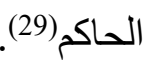

ومسن أهـم الوسـائل الإعلاميـة التـى تصـدر ها مؤسسـة الثـار قة للإعـلام قنـاة

الثارقة الفضائية وهى جهاز إعلامى ملتزم ومسئول، تأسس ليكون منارة من منار ات

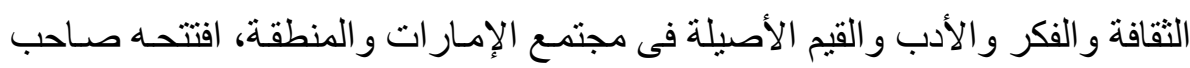
السمو الثيخ الدكتور سلطان بن محمد القاسمى عضو المجلس للإتحاد حاكم الثـارقة ليكون ضيفاً على كل بيت إمـار اتى فى الحادى عشر من شـهر فبراير / شباط عـام 1989، و لا يز ال يو اصل عطاءه الثرى منذ 21 عاماً على نفس المنهاج الذى تأسس عنس إنس

$$
\text { فى ضوئه. }
$$

تبنـى تلفزيـون الثـارقة القيم العربيـة و الإسـلامية، ويحتفى بهـا، ويعمـل على

إبر از هـا لتكـون أساسـاً فـى البنـاء الحضــارى ويجســ فكر تلفزيـون الثـارقة مفـاهيم السياسة العامة للبلاد فى التسامح و التفاهم و الاحتر ام. كمـا يتبنى وجهة النظر العربية و الإسلامية عند تناوله للمو اضيع السياسية و الأخلاقية و الدينية و الحضـارية و العلمية 
ويرسخ تلفزيون الثـارقة أسس بنـاء الأسرة فى ضوء القيم الأصيلة لمعتقدات وثقافة

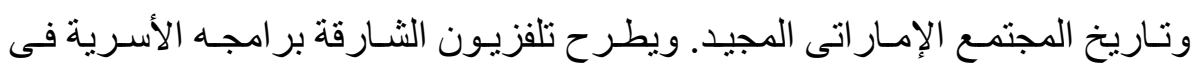
ضو ء احترام القيم الإسلامية والعربية الثـاملة لمجالات الحياة المختلفة.

يتبنى تلفزيون الثنارقة استر اتيجيات بر امجية تستقطب جميع فئات الأسرة من الأطفـال و المـر اهقين و الثـبـاب و الآبـاء و الأمهـات وكبـار السـن وذوى الاحتياجـات الخاصة. ويشجع تلفزيون الثـارقة جميع المبادئ التى تدعو إلى تعزيز الهويـة الوطنية بين مشـاهديه ويدعو هم إلى الفخر و الاعتـز از بهـا، ويقـدم تلفـزيون الثـارقة بـر امج ترفع مستوى ثقافة مشاهديه وتعزز رصيد هم العلمى حول التقـافة والتـاريخ و التر اث المحلى. ويسلط تلفزيون الثنارقة الضـوء على وجههـا الحضـارى عالمياً ويعـل على

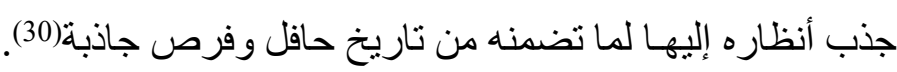

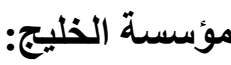

و هى مؤسسة خاصة تصد عنها جريدة الخليج اليوميـة الواسعة الانتشـار على

الصعيد المحلى والعربى، وقد صدر العدد الأول منها فى الثنارقة فى 17 أكتوبر سنة 1970 وبذلك تعتبر الخليج أول صحيفة يومية تصدر فيما بعد بدولة الإمار ات العربية المتحدة، وكذلك يصد عنها مجلة "الثروق" الأسبو عية وصدر العدد الأول منها فى بـ يونيو سنة 1970(31).

وفى 12 مارس 1996 أصدرت المؤسسة العدد الأول من مجلـة "الاقتصـادى" الأسبو عية، وكذلك صدر فى 1996/4/16 صـيفة "حلف توداى" اليوميـة باللغـة الإنجليزية، كما تصدر الدار مجلة "كل الأسرة" النسائية(32).

وقد صدرت صحيفة الخليج فى إمارة الثنارقة بتاريخ 19 أكتوبر سنة 1970، وتعد أول صحيفة يو مية فى الإمـار ات، وقد صدرت على يد الأخوين تريم و عبد الله عمران بعد أن أنهيا در استهما الجامعية فى القاهرة وكانت تحرر فى إمـارة الثـارقة 
وتطبع فى الكويت، وحيث تم وضـع الترتيبات الخاصـة بعملية الطباعـة فى الكويت ووصـول الصـحيفة فى يـوم صـدور ها نفسـهـ إلىى الثـارقة وذللك لأن هنـالك رحـلات طير ان شبه يومية تقوم بها الخطوط الجوية الكويتية إلى دبى. وتتنمى صـحيفة الخليج للصحافة الأهليـة فـى دولة الإمـار ات العربيـة المتحدة وينوى الإشر اف عليها ورسم سياساتها التحريريـة المؤسسون، أمـا رسمياً فإن وزارة الإعلام و الثقافة تمثل الجهة المسئولة عن تنفيذ القانون وحسب التقدير ات فيان مؤسســة الخليج تتمتع بمعدلات أعلى فى التوزيـع فى الثـار ع و إعلانـات أكثر مقارنـة مـع الصحف الأخرى، فى الوقت الذى تتو افر لديها عمال أقل من الصحيفتين الآخيرتين (الاتحاد، البيان) وتكلفـة إنتاج أقل بمعنى أنها تتميز بانخفاض نسبى فى عدد العهـالة والرواتب وترشيد النفقات إلى أبعد حد مقارنة مع الصحف الأخرى(33).

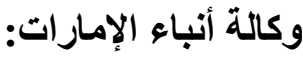
كان التفكير قد بدأ لإنشاء وكالة أنباء لدولـة الإمـار ات العربيـة المتحدة فى عـام 1973 وجرت فى هذا الصدد اتصـالات مـع وكالـة رويتر البريطانيـة، ثم أصدرتا وزارة الإعـلام والثقافة فى دولـة الإمـار ات العربيـة المتحدة قرار اً فـى شهر نـوفمبر

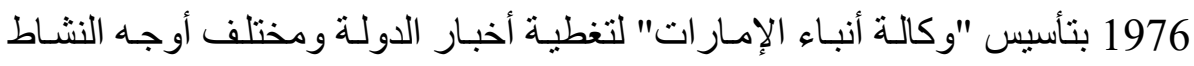
الذى تقوم به الأجهزة الحكومية و العمل على نشر ذلك بشكل واسع فى داخل الدولـة وخارجها. وقد بدأت وكالة أبناء الإمار ات عملها الفعلى يوم 18 يونيه 1977 ببث نشـرة أخبار محلية داخل الإمار ات التى يتكون منها الاتحاد.. و اعتبار اً من أول إبريل 1978 بدأت الوكالة تذيع نشرة أخبار فى دول الخليج وبيروت على شبكة وكالة رويتر.. و اعتبـار اً مـن أول أغسطس 1978 بدأت الوكالـة تذيع نشرة أخبـار على شبكة أنباء الثرق الأوسط المصرية بموجب اتفاق بين الوكالتين، وتتولى وزارة الإعلام فى دولة 
الإمار ات العربية المتحدة تغطية نفقات هذه الوكالة وذلك لأن الوكالـة لا تبيع أخبار هـا لعملائها، بل توزعها مجاناً على الصحف و الإذاعات والتليفزيون وكبار المسئولين بالدولة و المؤسسات الأخرى و الدو ائر الحكومية و غير ها(34).

ويوجد المركز الرئيسى للوكالة فى أبو ظبى (عاصمة الاتحـاد) ويتبعه ثمانية مكاتب داخلية على امتداد الدولة فى: الثـارقة، عجمـان، دبى، رأس الخيمـة، الفجيرة، أم القوين ومدينة العين التابعة لإمارة أبو ظبى، ومدينة زايد. وفى الخارج يوجد للوكالة 30 مر اسلاً فى و اشنطن ونيويورك وبـاريس ولندن وبروكسل، جنيف وبرلين ومدريد وتونس وبيروت ودمشتق وصفاء و عمـان و غير هـا

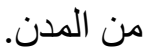

وتقوم وكالـة أنباء الإمـار ات بتوزيع الأخبـار المحلية التى تجمعها إلى جميع

سفار ات الدولة فى الخارج وجميع وكالات الأنباء العربية والصحف العربية فى جميع دول الخليج و إلى الصحف العربية التى تصدر فى أوروبا(35).

ووكالـة أنبـاء الإمـار ات عضـو فـى اتحساد وكـالات دول مجلس التعـاون لدول الخليج العربية واتحاد وكالات الأنباء العربية واتحاد وكالات الدول الإسلامية ومجمع وكالات دول عدم الانحياز . ويبلغ عدد العاملين فى وكالـة أنباء الإمـار ات داخل دولة الإمار ات العربية المتحدة 180 شخصـاً يشملون الصحفيين والإدارة يضـاف إلى ذلك 30 مر اسلاً فى خارج الدولة(36). وتهتم وكالة أنباء الإمارات بتنمية الكو ادر الوطنية على أسـاس أن هذه الكو ادر هى الأجدر على ترجمة طموحات الدولة وأبناءها والتحدث بلغة مفهومة عن إنجاز ات الدولة وتطلعاتها ومشكلاتها وتسليط الضوء على الكثير من الجو انب التى لا يمكن لغير الكوادر الوطنية فهمها بصورة كاملة وشاملة(37). 
المدن الإعلامية الحرة فى دولة الإمارات:

\section{المنطقة الحرة للإعلام وتكنولوجيا المعلومات فى دبى (تيكوم):}

إن ثورة تكنولوجيا المعلومات و الاتصال أحدثت نقلة نو عية هائلة فى نمط حياة

الإنسان وأسـاليب عمله و علاقاته بالعـالم من حوله الذى اخترقت هذه الثورة حدوده

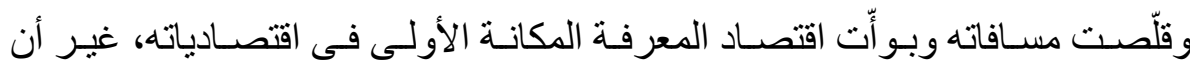
الاستفادة من تلك الثورة يتطلب تذليل الفجوة الرقمية والإعلاميـة التى مـا فتنئت تتسـع

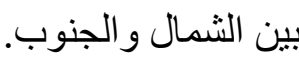

و عمدت دولة الإمار ات فى مسعاها إلى جسر تلك الهوة وتوطين التكنولوجيـا

وجلب الاستثمار ات وتتويع مصـادر الدخل، إلى إقامـة مدن إعلاميـة حرة، مـع بدايـة

الألفية الجديدة، وأخذت فى التوسع أكثر فأكثر فى عدد من إمارات الدولة.

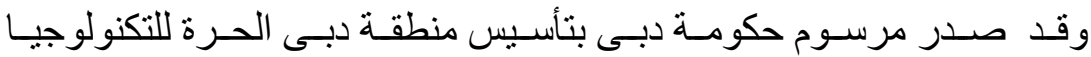

و التجارة الإلكترونية والإعلام بتاريخ 31 يناير 2000 وتم تعديله بالقانون رقم 9 لعام 2003 و التعديل الصـادر بالقـانون رقم 11 لعـام 2004 و القانون رقم 1 لعـام 2006 لجعل دبسى مركزاً للتكنولوجيـا والتجـارة الإلكترونيـة و الإعـلام وكهيئة اعتباريـة لهـا استقلالها المالى و الإدارى فى المنطقة الحرة.

وتمثل تيكوم الذراع الاستثمارى الخاص بـالإعلام و التكنولوجيا التابع لثركة دبى القابضة و هى بذلك تملك مجمو عة من السلطات و المسئوليات فهى تشرف على الأعمال التجارية داخلها وتقدم خدمات الاتصـالات و الإنترنت ومن جانب آخر تمثل هيئـة غير ربحيـة تمثنل سلطة منطقة دبسى الحرة للتكنولوجيـا والتجـارة الإلكترونيـة والإعلام. وتنتمل تيكوم على ثمانية قطاعات هى(38): 1- مدينة دبى للإعلام Dubai Media City DMC 
الإعلام الإماراتي النشأة والتطور

2- مدنية دبى للإنترنت Dubai Internet City DIC

3- قرية دبى للمعرفة Dubai Knowledge Village

4- مدينة دبى للاستديو هات Dubai Studio City

5- منطقة دبى للتعهيد Dubai Outsource Zone

6- منطقة الإنتاج الإعلامية الدولية International Media Production Zone

7 - مجمع دبى للتقنيات الحيوية و الأبحاث Dubiotech

8- إى هوستغ داتـافورت EHosting Datafort لخدمات الاستضـافة و الحمايـة

$$
\text { الإلكترونية. }
$$

ومن أبرز المدن التى تحتوى عليها المنطقة الحرة فى دبى مدينة دبى للإعـلام،

و إن كانــت مدينـة دبـى حديثـة العهد كغير هـا مـن المـدن الإعلاميـة العربيـة، إلا أنهـا

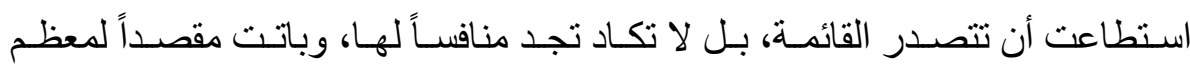

الثركات العالميـة والعربيـة الإعلاميـة، حتى يصـب إيجاد شـاعر فيها لمؤسسـات أو

شركات جديدة، فتشير الإحصائيات الصادرة عن إدارة مدينـة دبى الإعلاميـة، إلى أن

نسبة الإشغال فيها، بلغت 100\%، وأن هناك نية للتوسع لاستقطاب أعداد أكبر من

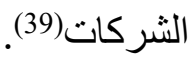

\section{المنطقة الحرة للإعلام فى أبو ظبى:}

فـى 12 أكتـوبر 2008 أطلقـت أبـو ظبـى مـن خـلال شـركة مبادلـة الـذراع

الاستثمارى لإمارة أبو ظبى منطقة جديدة لإنثاء المحتوى الإعلامى باسم Twotour

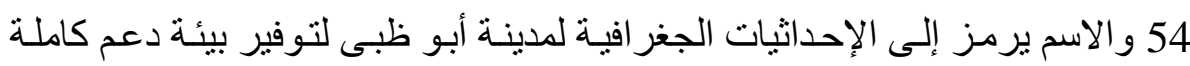

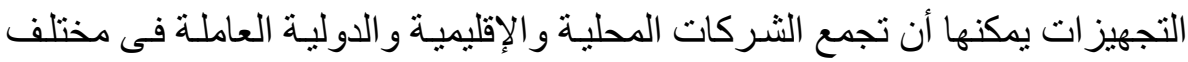


قطاعات الإعلام من صناعة الأفلام والبث و النشر إلى التكنولوجيا الرقمية و الموسيقى وتمتد لتشمل الرسوم المتحركة والمحتوى الرقمى وسائر الفنون(40). و هيئة المنطقة الإعلامية هى مركز للامتياز فمجال ابتكار المحتوى الإعلامى و الترفيهى العربى، صُمدت لتحفيز الإبداع ولتلهم مطورى المحتوى فى صناعات الأفلام و البث و التكنولوجيا الرقميـة و الألعاب و النشر و الموسيقى. أنتئت الهيئة لتقدّم بيئة دعم وتعاون تسمح بإنشاء صناعة إعلام وتطوير المحتوى على مستوى عالمى فى أبو ظبى لمنطقة الشرق الأوسط وشمال إفريقيا. تسعى هيئة المنطقة الإعلامية إلى تطوير مستوى عالمى من وسـائل الإعلام العربية والمحتوى الترفيهى، من العرب وللعرب، ووضع أبو ظبى فى مركز إقليمى هـى لتحفيز الإبـاع ولتلهم مطورى المحتوى فى صـناعات الأفـلام والبـث و التكنولوجيـا الرقمية و الألعاب و النشر و الموسيقى.

وتحقيقاً لهذا الهدف، تقوم هيئة المنطقة الإعلاميـة على ثناث دعائم أساسية هى: Twofour54 "تدريب" (أكاديمية التدريب)، Twofour54 "ابتكار " (الابتكار و الدعم)، Twofour54 "إنتاج" (تسـهيلات عالميـة للإنتاج ومـا بعد الإنتاج)، والتى تحظى جميعهـا بالتسـهيلات التى توفرهـا Twofour54 "تو اصـل" (نقطـة تو اصـل واحدة). وتوفر Twofour54 مركز اً للتعليم المهنى وتمويل لصناعة وسـائل الإعلام ودعم الأعمال التجارية والإنتاج على مستوى عالمى(41). - Twofour54 تـدريب: تعتبـر أول أكاديميـة مـن نو عهـا للتـدريب المهنى فـى المنطقة وواحدة من الدعائم الرئيسية التى تقوم عليها الهيئة. ما توصلت إليه تقنيات العصر ، إضـافة إلى إدارة الأصـول الإعلاميـة وخدمات

$$
\text { البث لشركائها. }
$$


- ابتكـار: تقدم الدعم و التمويـل للمؤسسـات الإعلاميـة و الترفيهيـة الجديدة أو التى هى فى طور النمو، وللأفكار الإبداعية الواعدة.

المنطقة الحرة للإعلام فى رأس الخيمة:

أنثأت مدينة ر أس الخيمة الحرة للإعلام و السينما فى 3 ينـاير 2006 بواسطة

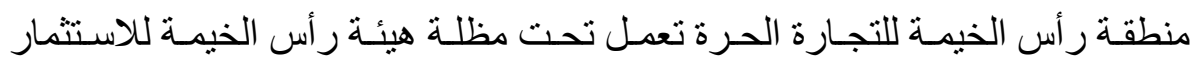
التابعة لحكومـة رأس الخيمة. وقد منحت هيئة ر أس الخيمـة للاستثمار الهيئة لثـركة

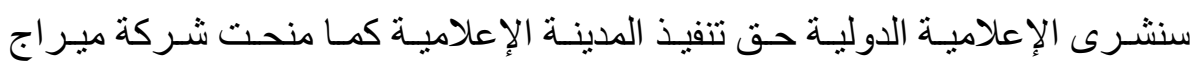
الأمريكية حق التنفيذ وتشغيل و إدارة مدينة الإنتاج السينمائى.

وتستفيد المدينة الإعلامية فى رأس الخيمة من المميز ات التى تتمتع بها منطقة

رأس الخيمة لتجارة الحرة كواحدة من أسرع المنـاطق الحرة نمواً فى دولة الإمـار ات العربية المتحدة و هى تهدف إلى تحقيق عدد من الأهداف منها(42):

1- دعم أهداف حكومة رأس الخيمة فى تسويق الموقع المتميز للإمارة وفتح المجال أمام مؤسسات الإنتاج السينمائى العالمية للاستفادة من هذه الإمكانات.

2- جنب المؤسسات و الكو ادر الإعلامية من جميع أنحاء العالم للعمل فى الإمارة بمـا

$$
\text { يعود بالنفع على الاقتصاد الوطنى. }
$$

3- تأســيس بنيـة تحتيـة الاستضــافة المؤسسـات الإعلاميـة ومحطـات التلبفزيـون

$$
\text { و استديو هات و إنتاج السمعيات و المرئيات. }
$$

4- أن تتو اكب المدينة الإعلامية مع مميزات الاستثمار فى المنطقة الحرة بمـا يمكن المستثمرين من إنشاء المؤسسات الإعلامية الخاصة مثل الاستديو هات و المطابع

$$
\text { و الوكالات الإعلانية والصحف. }
$$




\section{وتشم ل مجالات عمل مدينة رأس الخيمة للإعلام على المجالات التالية:}

1- النشـر للصـــافة الورقيـة و المجـلات، و الكتـب و المـو اد الإعلاميـة والترويجيـة

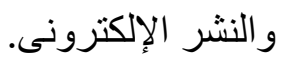

2- خدمات البث الإذاعى و التليفزيونى و الخدمات الإنتاجيـة المصـاحبة لـه وخدمات

$$
\text { البث الأرضى وخدمات إعادة البث. }
$$

3- إنتاج وتوزيع الأفلام السينمائية وخدمات التصوير السينمائى وترخيص مواقع

$$
\text { التصوير. }
$$

4- خـدمات التـرويج والتســويق الإعلامسى و الإعـلان ووكـالات العلاقـات العامــة

و الاتصـال و إدارة حقوق الملكيـة الفكريـة و البيـع و الثـــر اء و التمثيـل الإعلامسى

$$
\text { وخدمات هوية الثركات. }
$$

5- خدمات وكـالات المعلومـات ومنهـا خدمات وكـالات الأنبـاء وخدمات البحوث

$$
\text { و الدر اسات الإعلامية وخدمات المعلومات. }
$$

6- إنتاج الموسيقى و الترفيه بمـا فى ذلك إنتاج التسجيلات الموسيقية و إدارة حقوق الملكيـة الفكريـة والترويج للأعمـال الموسيقية و إدارة المناسبات و إدارة حدائق

$$
\text { الألعاب و الترفيه الحى و الفنون المسرحية و الرقص. }
$$

7 - خدمات الإعـلام الجديـد مثنل تصـميم و إدارة مواقع الإنترنـت وتقديم الخدمات

التفاعلية و البث على شبكة الإنترنت وتطوير برمجيات الإعلام الجديد والوسـائط

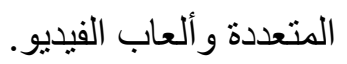

8- خدمات الـدعم الإعلامسى التى تشـمل تقديم خدمات و أجهزة الأقمـار الصـناعية

وخدمات الهاتف النقال وخدمات تـأجير المعدات والأجهزة الإعلاميـة للإنتاج

$$
\text { وخدمات الأرشفة و التوزيع. }
$$


9ـ الخـدمات الاستشــارية مثـل خـدمات الاستشــارة القانونيــة وخـدمات مر اجعـة الحسابات و المحاسبة والموارد البشرية و التسويق و إدارة المشاريع.

\section{المنطقة الحرة للإعلام فى الفجيرة:}

تتبع مدينة الفجيرة للإعلام لحكومة الفجيرة ويطلق عليها مدينة الإبداع وهى عبارة عن تجمع للمبدعين فى مجال الإعلام وقد تأسست بموجب مرسوم أميرى وتم الإعـلان عنهـا فـى 29 نـوفمبر 2005 كمشـرو ع إعلامسى و إبـداعى تسـى حكومـة الفجيـرة مـن خلالـه إلـى إحـاث قفزة نوعيـة فـى قطــاع الإعـلام المرئسى و المسـوع ع

$$
\text { و المقروء فى الإمارة. }
$$

وتهدف مدينة الإبداع التى تم إطلاقها من قبل مجمو عـة الفجيرة للإعلام كبديل لمدينـة دبـى للإعـام إلى جذب مقدمى خدمات البـث التلفزيونى و الإذاعى الإِقليمين و الدوليين إلى مدينة الفجيرة فى دولة الإمـار ات العربيـة المتحدة. بالإضـافة إلى ذلك، تهدف المدينة إلى تقديم الخدمات الإبداعية لوسائل الإعلام.

وقـد تكلفت المرحلـة الأولـى مـن عمليـة التطــوير الهائلــة 50 مليـون دولار أمريكى. تتكون المنطقة الحرة من مجمع تبلغ مسـاحته 200000 متر مربع يقع على امتداد طريق الفجيرة السريع الذى يتصل بطريق الإمار ات المؤدى إلى دبى. ولقد تم إنجاز المرحلة الأولى منها فى عام 2007(43). وقد أطلقت مدينة الفجيرة للإعلام لكى تكون منطقة جذب إعلامى حرة قادرة على الاسـتثمار فى المجـال الإعـلا مسى وهـى تسـى لتعزيـز موقـع إمـارة الفجيـرة الاستر اتيجي الذى يعد نافذة شرقية لدولة الإمار ات على البحار المفتوحة كخليج عمان و المحيط الهندى وتشمل الأهداف التى تسعى إلى تحقيقها ما يلى (44): 1- تعزيز الاهتمام العالمى بالإمار ات وتتميـة قطاع الاستثمار ات الأجنبية المباثـرة 
الإعلام الإماراتي النشأة والتطور

2- تأسيس و إطلاق المحطات التليفزيونية.

3- تأسيس بنية تحتية للاستديو هات الخاصة بإنتاج الدر اما العربية و المحلية.

4- خلق آلية لترخيص المجلات و الوسائل الإعلامية.

5- نتجيع إقامة المهرجانات الإعلامية والثقافية. 
السيد بخيت وآخرون، الإعلام الإماراتى.. الواقع والقضايا والممارسات، (الثارقة: دار الخليج

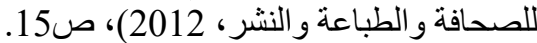

للحمد بن عوض المشيخى، الإعلام فى الخليج العربى.. واقعه ومستقبله، (دبى: مكتبة الفلاح

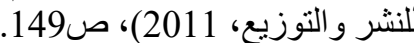

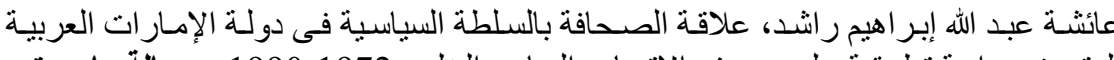

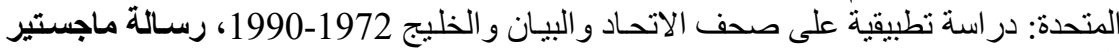

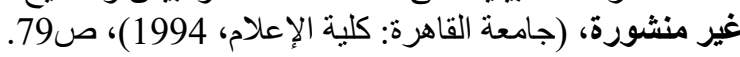

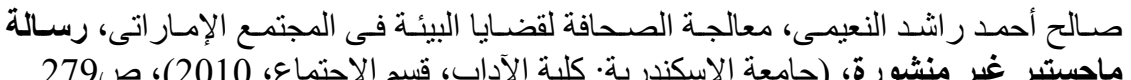

عباء حسن، هويتتا الإعلامية، (أبو طبى: هيئة الفجيرة للنقافة و الإعلام، 2010)، ص20.

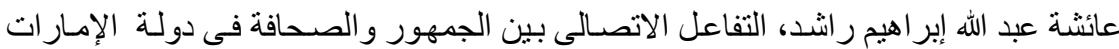

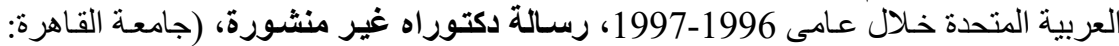

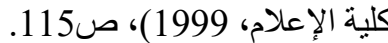

خالد الخاجة، للإعلام فى الإمارات تاريخ، جريدة البيان، 17 سبتمبر 2013.

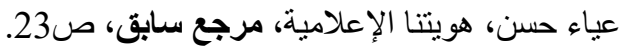

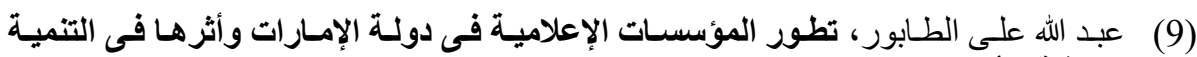

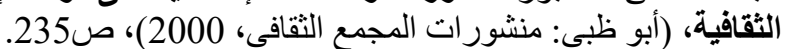

(10) عبد الله النويس، وسائل الإعلام فى دولة الإمارات العربية المتحدة، (أبو ظبى: دار الصحوة

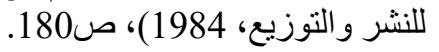

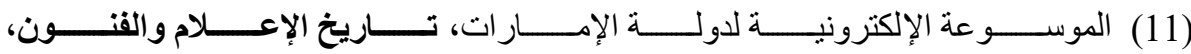
.http://www.uaepedia.ae/index.php

1السيد بخيت وآخرون، الإعلام الإمار اتى.. الواقعو القضايا و الممارسات، مرجع سابق، ص29.

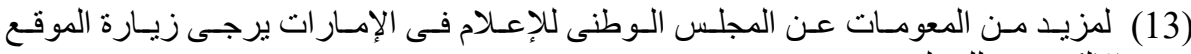

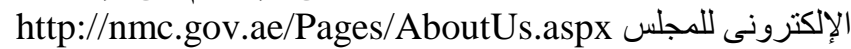

(14) قانون اتحادى رقم (15) لسنة 1980 فى شأن المطبو عات و النشر ، المادة رقم (2).

(15) قانون اتحادى رقم (15) لسنة 1980 فى شأن المطبو عات والنشر، المادة رقم (24).

(16) قانون اتحادى رقم (15) لسنة 1980 فى شأن المطبو عات و النشر، المادة رقم (25).

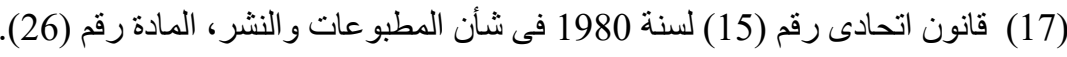

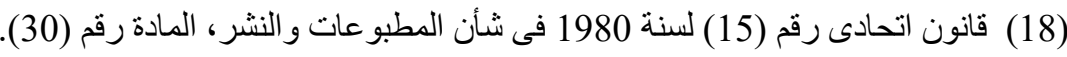

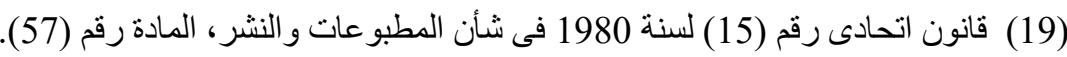


http://www.admedia.ae الموقع الرسمى لمؤسسة أبو ظبى للإعلام (20)

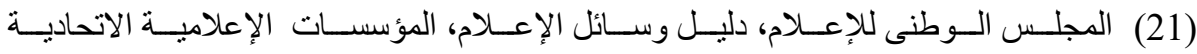
http://nmc.gov.ae/pages/MediaDirectory.aspx

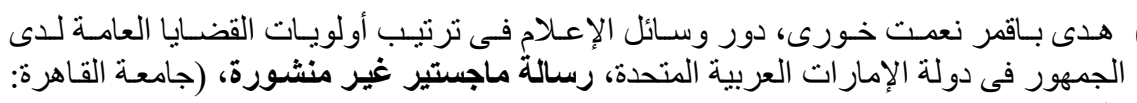

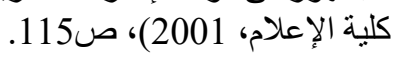

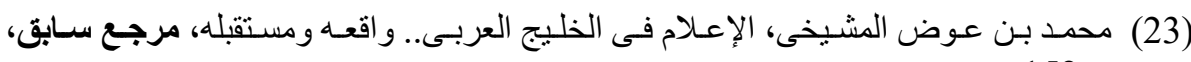

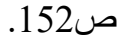

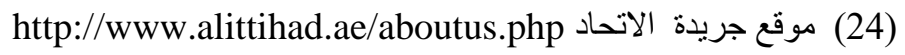

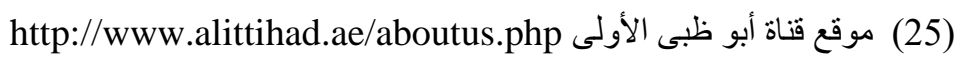

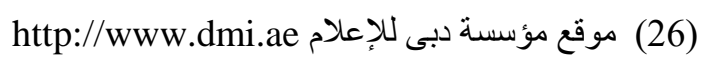

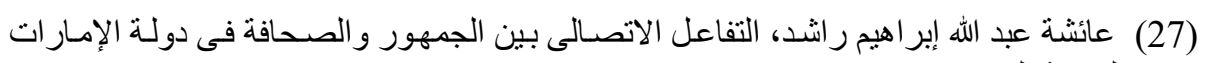

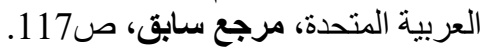

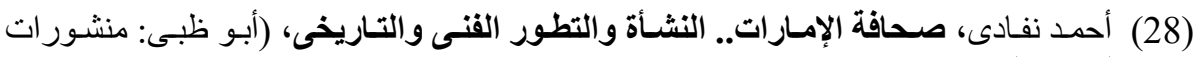
المجمع الثقافى، 1996)، ص131 الإن،

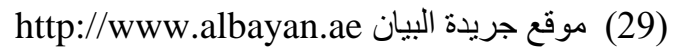

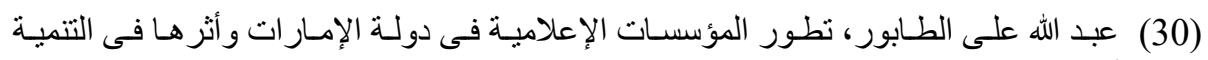
الثقافية، مرجع سابق، ص138.

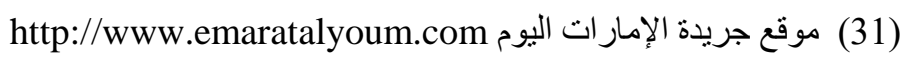

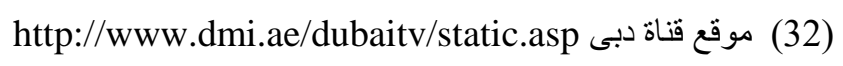

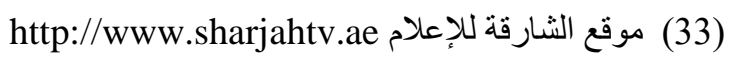

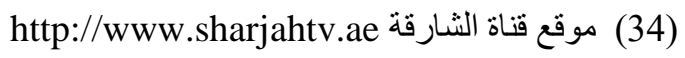

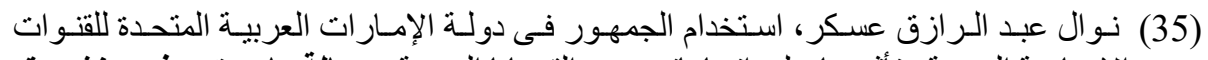

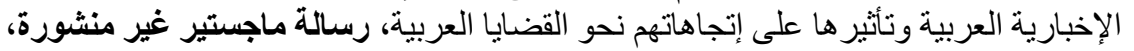

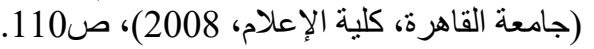

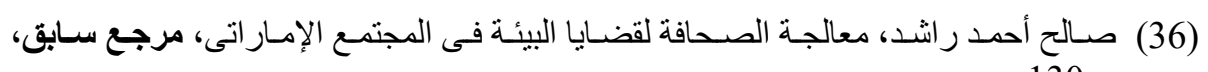

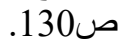

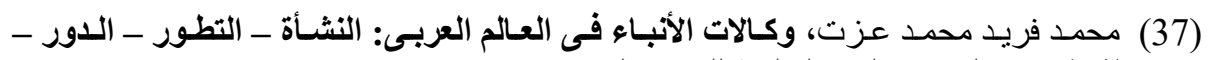
الفعاليات، (القاهرة: الدار العالمية للنشر و التوزيع، 2010)، ص25.

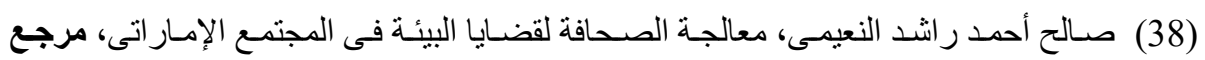
سابق، ص283. http://www.wam.org.ae الموقع الرسمى لوكالة أنباء الإمارات (وام) (39) 
(40) السيد بخيت و آخـرون، الإعـلام الإمـار اتى.. الو اقع و القضـايا والممارسـات، مرجـع سـابق،

(41) عباس مصطفى صادق، المدن الإعلامية الحرة فى دولة الإمارات، (أبو ظبى: المركز الثقافى

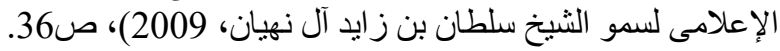

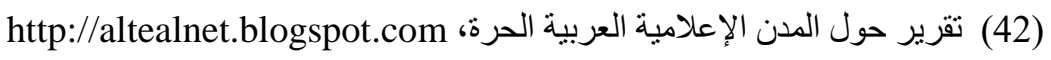

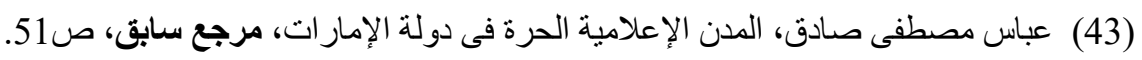

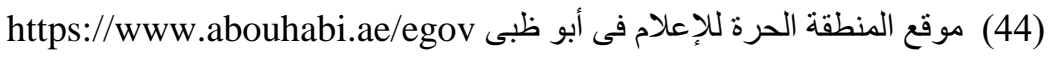

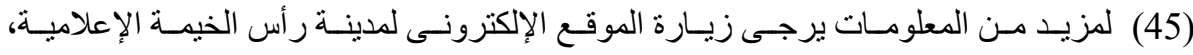

http://rakmediacity.ae

http://www.fmg.ae/home/index.php الموقع الإلكترونى لمدينة الفجيرة الإعلامية، (46)

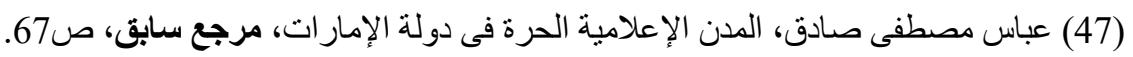

